\title{
Processioner: Indledning
}

\author{
HANS J. LUNDAGER JENSEN
}

\begin{abstract}
ENGLISH ABSTRACT: The introduction to this thematic issue of Religionsvidenskabeligt Tidsskrift provides an overview of contemporary lexical discussions of and explications of processions, a discussion of reasons for a certain tendency to forget about processions and a consideration of processions in relation to basic theories of ritual.
\end{abstract}

DANSK RESUME: Indledningen til dette temanummer af Religionsvidenskabeligt Tidsskrift giver en oversigt over nutidige leksikale redegørelser for og overvejelser over definitioner af fænomenet procession, drøfter årsager til religionsvidenskabens 'processionsglemsel' og placerer processioner i forhold til grundlaggende ritualteori.

KEYWORDS: processions; archaic religion; Ronald L. Grimes; Bernhard Lang; Annemarie Gronover; Emile Durkheim; Roy A. Rappaport; Rudolf Otto.

Den religionshistoriske forskningsenhed ved Afdeling for Religionsvidenskab ved Aarhus Universitet har arbejdet med emnet processioner i tre omgange. Først afholdt vi i efteråret 2015 et forløb om processioner som religiøst fænomen. Forløbet bestod i fremlæggelser af erfaringer og tanker om emnet, primært ud fra deltagernes kompetencer inden for deres forskellige historiske og regionale fagområder. Dernæst samlede vi bidrag sammen til mundtlige fremlæggelser og korte diskussioner på et ét-dages seminar i december 2016. Og endelig publiceres hermed et større antal af disse bidrag i form af artiklerne i dette temanummer.

Baggrunden for dette initiativ var en fornemmelse af et misforhold imellem på en ene side processioners reelle betydning i religionshistorien, herunder også i aktuelle religioner, og på den anden side den ringe plads de hidtil har indtaget i gængse religionsfænomenologiske og religionshistoriske fremstillinger. Processioner forekommer på tværs af skel imellem religioner; og de forekommer i nutiden, som de har forekommet i flere tusind år - og så er fænomenet sandsynligvis meget ældre endnu. På den ene side har vi at gøre med undertiden stærkt spektakulære begivenheder der nærmest af sig selv tiltrækker opmærksomhed og interesse. Men på den anden side har de ikke i den religionsvidenskabelige forskning haft en opmærksomhed som svarer til det der kan være deres reelle betydning. Alle forbinder 
noget med offer, helligsteder, myter, tabu, shamaner og initiationsritualer - og det er nemt at komme på ikke kun empiriske og historiske eksempler, men også på sofistikeret teoridannelse. Men måske har processioner været - og er endnu - lige så vigtige? Med dette temanummer har vi den ambition at etablere processioner som et proto-typisk religiøst fænomen, en obligatorisk del af enhver religionsfænomenologi (og gennemgange deraf!) - et fænomen som ikke hører til religionernes yderkanter, men til deres kerne.

Uden tvivl er den relative betydning af processioner i enkelte religioner eller disses historiske skikkelser ikke den samme. Og hvis det er rimeligt at tale om en slags 'processions-glemsel', kan denne formentlig delvis forklares med en 'processionssvaghed' i de protestantiske kristendomsformer. Det er disse der direkte eller indirekte har været en baggrund og omverden for religionsvidenskaben som akademisk felt - positivt eller negativt - som erklæret positivt udgangspunkt for en interesse i religion i mange former (som fx Rudolf Otto) eller som erklæret negativt udgangspunkt for samme interesse (fx James George Frazer). Protestantiske kristendomsformer har præget generelle forventninger til religion, eller til autentisk, 'rigtig' religion, både hos forskere og i en bredere vestlig offentlighed, i retning af at det centralt religiøse skulle findes i meddelelser, belæringer, principper, trosforestillinger, alt det der i en deskriptiv betydning af ordet kan kaldes 'teologi'. Sådanne forventninger til hvad religion var, indebar en samtidig marginalisering af 'praksis', altså handlinger. Ritualer og livsførelsesprincipper måtte afledes af trosforestillinger; de blev ikke af disse forskere anset som sideordnede med eller endda primære i forhold til forestillinger.

Modpolen til en sådan skævhed er velkendt og veletableret i religionsforskningens historie: Den praksis-orienterede, der udsprang af Robertson Smiths Lectures on the Religion of the Semites (1894), og som fik et monument i Durkheims Les formes élémentaires de la vie religieuse (1912). Her var det ikke i forestillinger, men i handlinger, man skulle søge de mest fundamentale religiøse fænomener. Men, måske fordi religionsforskningen generelt fortsat havde fokus på tekstligt formidlede informationer. blev det bestemte typer af praksis, der tiltrak sig opmærksomheden, i særdeleshed ofringer og, senere, initiationer.

Der kan være endnu en grund til at processioner er blevet overset som et (muligt!) centralt religiøst fænomen. Selv om processioner er prominent til stede i mange nutidige religionsformer (og i sekulære offentlige skikkelser, uden relation til etablerede religionsformer i nutiden), virker de ofte fortidige, som 'survivals' fra tidligere religionsformer. Det er ikke svært i en romersk-katolsk procession med en lokal helgen-statue eller i en indisk procession med et lokalt gudebillede at genkende en tilsvarende procession fra oldtidens Egypten eller Grækenland. En artikel af Daniel Overmyer fra 1997 om processioner med hhv. lokale kinesiske guddomme og kristne helgener i Europa giver instruktive og inspirerende eksempler. Han nævner desuden at processioner af den type han beskriver, bør anses for eksempler 
på hvordan religioner, der ikke er historisk forbundne, udvikler former der relaterer sig til behov der gives i før-moderne agerbrugsbaserede samfund'. ${ }^{1}$

Dette umiddelbare indtryk er uden tvivl rigtigt. En mere præcis bestemmelse af den type religion hvor man kan antage at processioner har fået en særlig prominent plads, vil være arkaiske religioner (if. Robert Bellahs historiske religionstypologi ${ }^{2}$ ), dvs. den type religion som fungerede sammen med og som var med til at skabe de tidligste statslige samfund med deres byer, kongedømmer, udførlige offer-ritualer, monumentalbyggerier, præstelige funktionærer og himmelske guder i (nogenlunde) systematiserede panteon'er - i hvert fald er det den type processioner som Overmyer tænkte på, hvor hellige genstande præsenteres for en større skare af tilskuere. Arkaisk religion har imidlertid en dobbelthed i religionsforskningen. På den ene side er den på mange måder velbelyst. På den anden side er arkaiske religioner oftest blevet beskrevet som kulturelle isolater af specialister veludrustet med en stor (og for mere komparativt indstillede religionsforskere intimiderende) kompetence i de enkelte religioners arkæologiske, sproglige og historiske forhold, men uden større interesse for, endsige indsigt $i$, religionstyper og generelle religiøse forhold.

Endelig kan man som den tredje grund nævne at der har været en tilbøjelighed i religionsvidenskaben til at hente de basale religionsfænomenologiske temaer i antropologiske, snarere end i religionshistoriske sammenhænge, dvs. i religion i små samfund, snarere end i store samfund, hvor religionen skulle engagere tusindvis af mennesker samtidig. Ofringer kan selvfølgelig godt gennemføres på vegne af store mængder af mennesker. Men det er tvivlsomt hvor mange mennesker der faktisk kan have overværet et offerritual (for ikke at tale om hvor stor en rækkevidde en gennemført potlatch kan have haft - for nu at nævne et fænomen der formentlig vil få langt flere hits end processioner i en oversigt over hvad religionsforskere og tænkere har betragtet som vigtigt og interessant). Processioner er under alle omstændigheder en form for massekommunikation, og det er nok umiddelbart plausibelt at antage at den mest elementære form for kommunikation af hellige genstandes og store og mindre guders navne, udseende, identitet og betydning i større bysamfund har været netop igennem processioner.

Men hvad skal man forstå ved 'procession'? I drøftelserne af processioner er vi gået pragmatisk ud fra to lettilgængelige leksikon-definitioner. Den ene er af Ronald L. Grimes i Encyclopedia of Religion (fra førsteudgaven 1985). Grimes definerer procession som 'en gruppes lineært ordnede, højtidelige bevægelser igennem et forudindrettet rum [der menes: $i$ et by-rum eller ad forberedte ruter i et landskab, HJLJ] til en kendt destination for at bevidne, bære en værdifuld genstand, udføre et ritual, opfylde et løfte, opnå en fortjeneste eller besøge et helligsted'. ${ }^{3}$ Igennem Grimes'

11 "My thesis is that the similarities manifested by these originally different cults indicate a convergence of beliefs and customs based on the needs of pre-modern agricultural village life" (Overmyer 1997, 216).

2 Jf. Bellah 1964, 364-365; 2011, 210-264.

3 "the linearly ordered, solemn movement of a group through chartered space to a known destination to give witness, bear an esteemed object, perform a rite, fulfill a vow, gain merit, or visit a shrine" (Grimes 2005, 7416). 
beskrivelse får man et indtryk af vanskelighederne ved at forsøge sig med en mere præcis definition af hvad en procession er. På den ene side giver det umiddelbart god mening at isolere et sæt af fænomener såsom (Grimes' eksempler) offentlig transport af guddomme under den babyloniske akitu-fest, romersk-katolsk frembæring af en hostie ved et Corpus Christi-optog, og fremvisning af erobrede skatte ved et antik-romersk triumfindtog, og sætte dem i kontrast til beslægtede, men ikke identiske fænomener. På den anden side er overgangene i praksis flydende. Parader og militære marcher er if. Grimes 'ekspansive og celebrerende' hhv. 'martialske og aggressive', og typisk hurtige, mens processioner (vi bør nok forstå: som et særlig religiøst fænomen) er højtidelige eller meditative og typisk langsomme. Deltagelse i processioner er mere begrænset, parader mere åbne; men processioner kan i denne henseende have en tendens til at forvandle sig til parader. Kapløb, der også kan være ritualiserede lige som processioner, er agonistiske, dvs. beregnet på at etablere en forskel imellem deltagerne, mens processionernes deltagere ankommer samtidigt eller på et forhånd aftalte tidspunkt. Processioners ankomststed er kendt på forhånd, i modsætning til fx ritualiseret jagt. Processioner har et ankomststed, i modsætning til ritualiseret dans. Det rum, processionen bevæger sig igennem, er forberedt i forvejen, i modsætning til pilgrimsvandring, der går igennem landskaber der ikke behøver at være kendt i forvejen af deltagerne. I modsætning til andre ritualiserede handlinger som initiationsritualer eller ofringer, som normalt har et erklæret formål, vil processioner antageligt finde sted uden at deltagerne har en præcis forestilling om noget bestemt formål. Men fremvisningen af en hellig genstand igennem en procession bekræfter genstandens 'hellighed', altså dens særlige status som en tabu-omgivet magt- og energikilde, og det sæt af symbolske værdier, der måtte være associeret med den.

Grimes' beskrivelser, som her er gengivet i stærkt forkortet form, viser et generelt problem med religionsfænomenologske kategorier. Som med andre centrale begreber i religionsvidenskaben (begyndende med selve begrebet 'religion'!) ser man sig uundgåeligt placeret $i$ et dilemma imellem en dagligsproglig og derfor uundgåelig løs eller flydende forståelse af et begreb og en foreslået fagspecifik terminologi. Erfaringsmæssigt kan det være noget nært umuligt at opnå konsensus om en fagterminologi, fordi dagligsproglige forståelser bevidst eller ubevidst ustandselig interfererer, eller fordi en dagligsproglig nuance passer bedre til en given religions eller kulturs udgave af et fænomen end til en anden religions eller kulturs. Her vil det nok være mere fremkommeligt at anlægge en 'nominalistisk' tilgang og gøre det klart at definitionsdiskussioner angår den mest formålstjenlige terminologi. Det drejer sig altså ikke om hvad processioner er, men om hvad ordet procession med fordel kan foreslås at betyde. En sådan mindre dogmatisk-insisterende indstilling kan måske formidle imellem fagterminologiens indbyggede trang til digitale differentieringer og virkelighedens analogiske kontinuerlighed, altså mellem en urealistisk klarhed og en realistisk uklarhed. 
Den anden leksikale forklaring, som har været udgangspunkt for diskussionerne, er Bernhard Langs artikel "Processions" i Religions Past and Present fra 2015, ${ }^{4}$ der er delt i en religionsvidenskabelig og en kristen-liturgisk del. I den liturgiske del defineres procession, af latinsk processio, 'at gå fremad', kortfattet som 'en rituel bevægelse i moderat hastighed'. ${ }^{5}$ Vægten i den generelle del ligger ikke på en definition eller en afgrænsning fra beslægtede fænomener, men på at skelne fire grundtyper. Funktionelle processioner, som er de mest almindelige, er ritualiserede former for ordinær, ikke-ritualiseret bevægelse (som når præster træder ind i en kirke). Teofore processioner indeholder fremvisninger af kultbilleder eller symboler. Ved mimetiske processioner genopfører deltagerne en mytisk eller legendarisk begivenhed. Demonstrative processioner involverer store befolkningsgrupper. Som eksempel på en hybrid form nævnes Corpus Christi-processioner, som både er teofore (og formentlig mimetiske ved at erindre om den første nadver) og demonstrative ved at fremvise katolsk pragt som kontrast til protestantisk processions-puritanisme.

Disse fire former er rimeligt velafgrænsede og repræsentative former. Man kan nok med fordel erstatte kategorien 'teofor' ('bærende en guddom') med en mere almen 'hierofor' ('bærende en hellig genstand') der kan omfatte både ikoniske og an-ikoniske genstande og som er neutral i forhold til antropomorft-personaliserede forestillinger. Mens det måske med subtile argumenter kan hævdes at en Corpus Christi-procession er 'teofor', kan det ikke forsvares fx ved de processioner med arken, der berettes om i Det Gamle Testamente.

En tredje aktuel leksikal indføring i processioner er artiklen i Brill Dictionary of Religion fra 2006 af Annemarie Gronover. Her ligger vægten ikke på en formel definition som hos Grimes eller en typologisk oversigt som hos Lang - begge dele er mere implicit og dermed mindre overskueligt vævet ind i hendes fremstilling - men på processioners sociale funktioner, navnlig i nutiden, som fx i kontrasten imellem en religiøs gruppes interesse i selvudtryk og en turist-orienteret interesse i et visuelt scenarie, eller som i lokale gruppers strid om retten til et domæne (således i Nordirland) eller som et middel til nedtrapning af forskelle imellem grupper og dannelse af samhørighedsfølelse (som i kirkeligt-økumeniske processioner). Det bliver klart at religiøse processioner også er et nutidigt fænomen, at den enkelte procession typisk har flere funktioner eller opfylder flere behov samtidigt, og at samme funktion kan vurderes forskelligt, herunder også velvilligt eller fjendtligt, set fra hhv. deltagernes og tilskuernes side.

Disse tre indføringer i fænomenet (eller begrebet) procession angår processioners forskellige former og funktioner hver med sine vinkler. Samtidig går de ud fra at processioner under alle omstændigheder bør betragtes som en form for ritualer. Her kan man tilføje en slags strukturel-fænomenologisk overvejelse. Processioner hører formentlig til de mest basale ritualer der kan tænkes. Dette er også en grund til at processioner virker umiddelbart interessevækkende for de fleste. En processon vil i

4 Oversat fra den tyske udgave fra 1998-2007: Hans Dieter Betz et al., eds., Religion in Geschichte und Gegenwart: Handwörterbuch für Theologie und Religionswissenschaft, Tübingen: Mohr Siebeck.

5 "In the Christian cult, a procession (Lat. procession, 'moving forward') is a ritual movement at a moderate pace". 
første omgang sige at en gruppe mennesker ensretter deres handlinger: De bevæger sig imod et fælles mål og med samme hastighed. Dvs. at en procession er en fundamental mimetisk begivenhed. Den indebærer at deltagerne afbryder deres normale, individuelt bestemte placering ( $\mathrm{i}$ et rum, $\mathrm{fx}$ et byrum) og deres eventuelle bevægelser, der hver for sig har et mere eller mindre pragmatisk formål, for at underkaste sig en fælles vilje med et fælles projekt. Dette er kernen i al ritualitet, og det er, som fremhævet af Durkheim, dermed i sig selv den menneskeligt sociale handling par excellence - fordi enhver menneskelig socialitet forudsiger evnen til en temporær dispensation fra individuel autonomi (Durkheim 1994, 295. 497; 1995, 209. 352). For at sige det med Rappaport og i en abstrakt form der ser bort fra mulige konkrete forhindringer eller udvendigt pres: I princippet kan deltageren i en procession vælge at deltage hhv. overvære den eller ikke at deltage, hhv. overvære. Hvis han eller hun vælger ikke at deltage eller overvære, bevarer han eller hun sin autonomi og kan i princippet gå eller ikke gå hvor han eller hun måtte ville det. Men så bidrager han eller hun heller ikke til det fælles projekt, som processionen i sig selv er. Hvis der ikke er nogen som vil gå med, bliver der ingen procession. Afgørelsen om deltagelse er altså - igen: abstrakt og i princippet - for eller imod kollektivitet og fællesskab og altså for eller imod kultur (Rappaport 1999, 36f. 119).

Som ritual hører processionen til de simplest tænkelige. Der behøver ikke at være særlige genstande involveret, klædningsstykker, duftmidler, formularer, forklaringer. Den forudsætter en begyndelse og en afslutning - men ikke nogen bestemt type. Den kan have en markeret leder, men behøver det ikke. I princippet kræver en procession ikke andet end kroppenes samling, synkronisering og bevægelse $i$ en række, den ene efter den anden. Vel at mærke som en markering af noget, som tegngivning. Jægere, krigere, flygtninge kan gå i række. Dyr kan gå i række. Men her er der et konkret mål: et bytte, en fjende, et tilflugtssted, et sted at flytte sig hen til. Processionen er at gå i række med det primære formål at give betydning. Alt efter hvordan man forholder sig til definitionen af religion, vil man eventuelt skulle skelne imellem religiøse og ikke-religiøse processioner. ${ }^{6}$ Den religiøse procession vil i så fald være en procession med et religiøst formål. Men den menneskelige kultur begynder ikke med og er ikke funderet i den pragmatiske synkronisering af kroppene - den er funderet i og begynder med en ikke-pragmatisk tegngivning. Jf. Walter Burkert (1979, 37):

ritual is action redirected for demonstration. Characteristic features of ritual in this perspective are: the stereotyped pattern of action, independent of the actual situation and emotion; repetition and exaggeration to make up a kind of theatrical effect; and the function of communication.

6 Personligt finder jeg det mest meningsfuldt med Durkheim at gå ud fra at religion oprindeligt i den menneskelige kulturhistorie har været sammenfaldende med kultur (Durkheim sagde 'samfund') overhovedet, dvs. at der først i løbet af menneskehedens kulturelle evolutionshistorie er kommet en gradvis større forskel imellem religion og ikke-religion. En definition af religion der på forhånd sætter en kategorial forskel imellem religion og ikke-religion, vil være fundamentalt uhistorisk og uundgåeligt medføre en slet uendelighed af definitionsdiskussioner. 
Med kommunikation skal her ikke forstås kommunikation af noget bestemt, af et bestemt indhold, men selve den handling at kommunikere - det som hos Rappaport (1979, 173-175) er 'the obvious aspect of ritual', ritualets 'overflade', ikke dets (eventuelle) semantiske 'dybde'. Det er i 'overfladen' at ritualer er ritualer; i deres 'dybder' er de forskellige mytologier, teologier, ideologier. Pointen i processioner og andre ritualer er at signalere at noget er vigtigt.

At en gruppe mennesker stiller sig op og bevæger sig i en række, er i sig selv opmærksomhedsvækkende. Det bryder med den daglige og rutineprægede bevægelighedsmangfoldighed uden fælles og bestemt retning, der kun kan registreres uklart og (alt efter graden af intensitet) som mere eller mindre kaotisk, og som, hvis den skulle kaldes noget, ville være 'mylder', 'travlhed'. Man kan her henvise til Rudolf Ottos fænomenologiske analyse i hans Das Heilige (1927) af det elementært 'hellige' (præciseret som 'det numinøse'), hvis minimale kernefænomen var 'mirum' (og dets psykologiske modsvar 'stupor' $)^{7}$ - altså præcis det opmærksomhedsfremkaldende og interessevækkende i sig selv, abstraheret fra alle emotionelle og semantiske nuancer. Som Otto gjorde klart, hæfter der sig næsten automatisk to sidefænomener på det der påkalder sig opmærksomhed: på den ene side noget intimiderende, og på den anden side noget forventningsfuldt Er de mennesker der bevæger sig i række, potentielt voldelige, som ved en højre- eller venstre-fanatisk gadedemonstration? Eller er de underholdende, flotte, bringer de evt. gaver med sig? Processioner kan forsøge at holde sig på den neutrale midte: at signalere betydningsfuldhed uden hverken at true eller love. Men mange processioner vil naturligvis tendentielt betone den ene eller den anden af de to andre sider (eller dem begge, for dem der sympatiserer med truslen). Guddommen, hvis statue bæres i procession, kan velsigne, men også forbande.

Ved at udhæve sig selv ud af en ensartet-kaotisk normalitet foretager processionen den mest elementære semiotiske funktion: at etablere et tegn. Det mest elementære tegn er noget der adskiller sig fra en ikke-adskillelig omverden - der kan være mangfoldig-kaotisk (som mylderet i en myretue) eller homogent-kaotisk (som snemasser eller hav). Før det binære tegn, der får sin betydning fra en modsætning til et andet tegn, er der det ene tegn, der er noget, alene fordi det er udhævet og adskilt fra alt andet. ${ }^{8}$

Dette fordobles i den hierofore procession og indlægges 'fraktalt': Den fremadskridende gruppe af mennesker, der adskiller sig fra en ubestemt omverden, transporterer i sin midte en bestemt ting, hvis betydningsfuldhed får alle andre tings mulige betydningsfuldhed til at blegne til betydningsløshed - i det mindste i situationen. Tingens - gudebilledets, de hellige genstandes - ydre fremtræden vil givet-

Otto 1979, 29-37. Latinsk mirum: det forunderlige, besynderlige, påfaldende; stupor: forbavselse.

Således 'emblemet' hos Durkheim, der ikke primært betegner en særlig kulturel form (fx en klan) over for andre kulturelle former ( $\mathrm{fx}$ andre klaner), men eksistensen af en klan overhovedet over for fraværet af en klan (Durkheim 1994, 315; 1995, 221f.). Durkheims problematik var ikke hvordan en kultur adskiller sig fra andre kulturer, men hvordan menneskeligt liv adskiller sig fra ikkemenneskeligt liv. Ganske tæt på Durkheim var René Girards fundamental-semiotik: Det første tegn opstår med den ene der er udstødt af et kollektiv (R. Girard 1978, 108-113; 1987, 99-104). 
vis oftest bekræfte eller understøtte dens principielle betydningsfuldhed (kostbare materialer, klare farver og lignede), selv om det ikke kommunikeres klart på hvad måde den er betydningsfuld. Men denne betydningsfuldhed er på forhånd sikret af den betydningsfuldhed der ligger $i$ at en tydeligvis betydningsfuld gruppe mennesker tydeligvis signalerer at den er betydningsfuld. Og mennesket er et mimetisk dyr. Hvis andre mener at noget er betydningsfuldt, er det mest nærliggende på forhånd at antage at det er det nok. Det er ikke underligt at mange post-religiøse stater og civile samfund har taget processioner op igen, eller videreført og transformeret dem, fra militære fremvisninger af ellers skjult udstyr til karnevalsoptogs fremvisninger af attraktive kroppe og af imaginære og komiske modverdens-tableauer.

Interessant nok afslutter Lang den religionsvidenskabelige del af sin artikel med at understrege at 'processioner er fremragende egnet til religionsvidenskabelige eller historisk-antropologiske analyser' ${ }^{9}$ Det er også den fornemmelse som ligger bag den interesse for processioner som resulterer i nærværende nummer af RvT. Men den tilsyneladende umiddelbare og indlysende relevans står op imod en lige så unægtelig tendens i hidtidig religionsforskning til ikke at tilskrive processionerne nogen særskilt opmærksomhed. Som et lidt vilkårligt valgt eksempel kan nævnes Gilhus og Thomassons Oldtidens religioner fra 2010, en norsk lærebog om egyptisk, mesopotamisk, iransk, græsk, romersk og hellenistisk religion. Her åbnes kapitlerne om egyptisk og græsk religion (synes jeg: godt) med bredt anlagte beskrivelser over flere sider af vigtige processioner, hhv. Opetfesten med procession af gudebilleder fra det store Karnak-tempel til Luxor-templet og Panathenæerfestens procession til Parthenon-templet på Athens akropolis; i tilknytning til den sidstnævnte tilføjes (s. 90) at denne type fester utvivlsomt var den vigtigste form for religionsudøvelse i antikkens Grækenland. Den vel egentlig lige så prominente mesopotamiske akitufest, der også indeholdt en stor procession af gudebilleder, nævnt meget kortere (s. 74) og uden at det antydes at den kunne have haft en tilsvarende rolle i det religiøse liv i Mesopotamien. Mere slående er dog at ordet 'procession' ikke optræder i bogens indeks, men skal findes under 'fester og høytider', mens fx "offer" har 48 henvisninger, "magi, trolldom" har 20 og "mytologi" 19 henvisninger. Som det fremgår, er Oldtidens religioner faktisk særlig opmærksom på processioner. Alligevel regnes procession åbenbart ikke som et selvstændigt tema, en religionsfænomenologisk kategori in its own right.

En sådan undladelse, som nok er udtryk for en regulær 'processionsforglemmelse' (hhv. marginalisering eller måske endog fortrængning), gælder mange andre steder hvor man kunne forvente en selvstændig beskrivelse. Man kan blot orientere sig i indekserne i fremtrædende og meget brugte hånd- og lærebøger som: Malefijt, Religion and Culture (1968), Widengrens Religionsphänomenologie (1969), Ringgrens Religionens form och funktion (1972), Ringgren \& Stöms Religionerna i histo-

9 "Processions are admirably suited to analysis by religious studies or historical anthropology, since they not only reveal the social character of the religious cult but also bring religious offices and roles into plain view and reflect hierarchical structures in the organization of the procession. Religious content and functions are clearly apparent in them, such as the confident-inspiring function of the deity present in his or her symbol". 
rie och nutid (1974), The Penguin Dictionary of Religions (1984), Waardenburgs Religionen und Religion (1986), Padens Religious Worlds (1988), Gads religionsleksikon (1999), Kippenberg \& von Stuckrads Einführung in die Religionswissenschaft (2003), Gyldendals Religionshistorie (2. udg. 2011). Selvfølgelig vil det være uretfærdigt - ud fra hvad man kan mene er en mangel $i$ et indeks - at slutte at sagen selv så heller ikke forekommer eller nævnes. Det er meget muligt at processioner nævnes mere eller mindre en passant og formentlig gerne i forbindelse med omtale af en konkret religiøs ytring. 'Processions-forglemmelse' vil ikke sige uvidenhed om at processioner findes, men en undervurdering af deres betydning.

Hertil må så understreges at processioner ikke er lige centrale $i$ alle religioner. Tværtimod er der givetvis, som indledningsvis nævnt, processions-fjendtlighed eller -ubehag i bestemte religionstyper, som fx protestantiske former for kristendom. Det muligt særligt arkaiske ved processioner kan i så fald tænkes at modsvares af en tilsvarende 'aksial' afstandstagen fra netop processioner. Her er der nok et temafelt der kan fortjene sin egen undersøgelse. Hvis det er rimeligt klart at protestantisk kristendom har en rodfæstet anti-processions-indstilling, gælder det så også for andre 'aksiale' religioner? At der under alle omstændigheder er plads til forskning, fremgår af en bemærkning i Grimes' artikel om at der ikke (i 1987) var skrevet en omfattende videnskabelig undersøgelse af processioner siden den store artikel "Processions and Dances" i Encyclopedia of Religion and Ethics (ed. James Hasting; Vol. 10. 1918). ${ }^{10}$ At dømme efter Langs og Gronovers artikler så sagen ikke meget anderledes ud i det første årti af det nuværende århundrede.

Ambitionen med dette temanummer er altså at gøre opmærksom på procession som et selvstændigt og betydningsfuldt religiøst fænomen. Ambitionen strækker sig hverken til at postulere nogen slags fuldstændighed eller til at ville knæsætte en bestemt definition af eller doktrin om hvad der fra nu af bør forstås ved processioner. Af de tre leksikonartikler der her er henvist til, er det faktisk kun Grimes', der indleder med at forsøge en slags definition. De to andre underforstår fra begyndelsen at en dagligsproglig forståelse er tilstrækkelig til at beskrive former og funktioner. De enkelte artikler i dette nummer vil hver for sig forklare, mere eller mindre indgående, hvad de forstår ved en procession. Hensigten er at de tilsammen vil give et nuanceret indtryk af at processioner er et centralt religiøst fænomen, positivt eller negativt, noget der bør gøres og overværes eller noget der bør undlades og undgås.

Hver af artiklerne her er selvberoende. De er ikke forsøgt tilpasset til hinanden med hensyn til en ensartet terminologi eller redigeret som kapitler i en monografi, hvor der forudsættes kendskab til de foregående kapitler. Hver af dem har sin egen definition, eks- eller implicit. For den der måtte ønske at læse alle artikler, vil der uundgåeligt være en del redundans hvad angår de overordnede linjer. Til gengæld

10 Grimes, 2005, 7418: "In the 1910s A. E. Crawley wrote-in his article "Processions and Dances" in the Encyclopaedia of Religion and Ethics, edited by James Hastings, vol. 10 (Edinburgh, 1918) - that no comprehensive or scientific work on processions had yet been written. His observation is still largely true. (...) Rare is the book that includes a chapter, section, or even an index entry on processions.

Presently, data on processions are still largely to be found in works on the religion and ritual of a particular area or tradition or, more specifically, their festivals and pilgrimages". 
kan hver artikel tages ud af sammenhængen og læses og bruges uafhængigt af de andre artikler. Der er mange eksempler på processioner som kunne have været medtaget her, og som ville have været lige så gode eksempler. En blot nogenlunde dækkende præsentation af religiøse processioner i denne verdens religioner i fortid og nutid vil være en umulighed. Men med artiklerne i dette nummer vises i hvert fald at procession faktisk er et centralt religiøst fænomen.

\section{LITTERATUR}

Bellah, Robert N.

1964 "Religious Evolution", American Sociological Review 29 (3), 358-374. https://doi.org/10.2307/2091480

2011 Religion in Human Evolution. From the Paleolithic to the Axial Age, Cambridge, MA: The Belknap Press of Harvard University Press. https://doi.org/10.4159/harvard.9780674063099

Burkert, Walter

1979 Structure and History in Greek Mythology and Ritual, Berkeley: University of California Press.

Durkheim, Emile

1994 Les formes élémentaires de la vie religieuse. Le systemè totémique en Australie, Paris: Quadrige/PUF (1912).

1995 The Elementary Forms of Religious Life, transl. Karen E. Fields, New York: Free Press.

Gilhus, Ingvild Sælid \& Einar Thomassen

2010 Oldtidens religioner. Midtøstens og Middelhavsområdets religioner, Oslo: Pax.

Girard, René

1978 Des choses cachées depuis la fondation du monde, Paris: Bernard Grasset.

1987 Things Hidden since the Foundation of the World, transl. Stephen Bann \& Michael Metteer, London: The Athlon Press.

Grimes, Ronald L.

2005 “Procession (1987)", in: Lindsay Jones, ed., Encyclopedia of Religion, 2. ed., Detroit: Macmillan Reference, 7416-7418.

Gronover, Annemarie

2006 "Procession", in: Kocku von Stuckrad, ed., The Brill Dictionary of Religion, trans. Robert R. Barr, Leiden: Brill, 1508-1510.

Jensen, Tim, Mikael Rothstein \& Jørgen Podemann Sørensen, eds.

2011 Gyldendals Religionshistorie. Ritualer. Mytologi. Ikonografi, København: Gyldendal.

Lang, Bernhard

2015 "Processions", in: Hans Dieter Betz et al., eds., Religions Past and Present, Leiden: Brill. http://doi.org/10.1163/1877-5888_rpp_COM_024492

Malefijt, Annemarie de Waal

1968 Religion and Culture. An Introduction to Anthropology of Religion, Prospects Heights, Illinois: Waveland Press.

Otto, Rudolf

1979 Das Heilige. Über das Irrationale in der Idee des Göttlichen und sein Verhältnis zum Rationale, München: C.H. Beck (1917).

Overmyer, Daniel L.

1997 "Convergence: Chinese Gods and Christian Saints", Ching Feng, 215-232.

Paden, William

1994 Religious Worlds. The Comparative Study of Religion, Boston: Beacon Press. 
Rappaport, Roy A.

1979 "The Obvious Aspects of Ritual", in: Roy A. Rappaport, Ecology, Meaning, and Ritual, Berkeley, California: North Atlantic Books, 173-221.

1999 Ritual and Religion in the Making of Humanity, Cambridge: Cambridge University Press. https://doi.org/10.1017/CBO9780511814686

Ringgren, Helmer

1972 Religionens form och funktion, Lund: CWK Gleerup.

Ringgren, Helmer, \& Åke V. Ström

1974 Religionerna i historia och nutid, Verbum.

Smith, William Robertson

1894 Lectures on the Religion of the Semites, New Edition, London: Adam \& Charles Black.

Waardenburg, Jacques

1986 Religionen und Religion, Berlin: Walter de Gruyter. https://doi.org/10.1515/9783110852196

Widengren, Geo

1969 Religionsphänomenologie, Berlin: Walter de Gruyter.

Hans J. Lundager Jensen, professor, dr. theol., Afdeling for Religionsvidenskab, Aarhus Universitet

hj@cas.au.dk 